Plant protection and quarantine. 2016. Issue 62.

UDK 632.913.1 : 632.651

\author{
L.A. PYLYPENKO, PhD, D.Sc. \\ Institute of Plant Protection NAAS
}

\title{
A QUICKSCAN PEST RISK ANALYSIS FOR THE MELOIDOGYNE MALI
}

A quickscan pest risk analysis for the apple root-knot nematode Meloidogyne mali for the territory of Ukraine was performed. This assessment was initiated in response to the recent (2012/2013) interception of the apple root-knot nematode in the Netherlands and Italy and because of the species inclusion on the EPPO Alert List in 2014. The risk of M. mali introduction, establishment and economic impact in Ukraine was assessed as likely, which proved the need for specific statutory actions to be taken to prevent ingress of the apple rootknot nematode and mitigate its effects in Ukraine. It is stated that the detailed pest risk analysis is required.

\section{Meloidogyne mali, the apple root-knot nematode, quickscan pest risk analysis}

The genus Meloidogyne comprises over 100 described species [26], among which the most widely distributed and harmful plant-parasitic species represented by: M. acronea, M. arenaria, M. chitwoodi, M. enterolobii, M. ethiopica, M. exigua, M. fallax, M. graminicola, M. hapla, M. incognita, M. javanica and M. paranaensis [5-10, 17, 34-36]. Despite of these species high economic importance, their detection and identification to the species level still pose a huge challenge because of the very small inter-specific morphological and morphometric variation $[12,25]$. As such, $M$. enterolobii had been identified as $M$. arenaria, M. incognita or $M$. mayaguensis for the very long period of time [6,33]. The same as Meloidogyne mali, which only recently has been synonymized with Meloidogyne ulmi [6].

M. ulmi was first described from Italy in 2000, when large galls were found on the elm tree roots (Ulmus chenmoui Cheng) grown locally under a breeding programme targeted on resistance to the Dutch elm disease [32]. For many years Ul. chenmoui remained the only known host plant for M. ulmi. It was discussed that introduction of nematodes could take place accidentally along with the infected elm nursery stock imported from the Netherlands under the framework of breeding programme mentioned above.

The Dutch elm disease is caused by fungi Ophiostoma ulmi (Buisman) Melin \& Nannf. (1934) and O. Novo-ulmi Brazier (1991), and is spread by the elm bark beetles Scolytus multistriatus Marsham, 1802, Scolytus 
schevyrewi Semenov Tjan-Shansky, 1902 and Hylurgopinus rufipes Eichhiff, 1868 [6]. It is believed that the pathogens penetrate the plant through mechanical wounds and settle in xylem tissue, resulting in its plugging. This prevents delivery of water and nutrients to the rest of the plant, eventually killing it. The fungi also produce toxins that degrade plant cell.

Dutch elm disease is still a major factor limiting the distribution and cultivation of elms in the world, including Ukraine where it was first detected in 1929 within Holovanevsk forestry (Podillia) [3-4]. In 60 ${ }^{\text {th }}$, the disease spread widely in the forests situated in the western region of the country. During the next decade it was detected much wider (Opillia, Roztochia and Prykarpattia regions), but after that the epiphytoty went down. It was shown, that the manifestation of the disease depends on climatic conditions reaching severity during drought periods and suppression - after cold winter with sufficient precipitates. Nevertheless, the exact picture of disease etiology is still unknown [2].

Among other countries in Europe, the Netherlands was the first one to establish the breeding programme focused on resistance to the Dutch elm disease, for which elm seedlings were imported from throughout the world. Initially the trial center was based in Baarn, which was moved to Wageningen later on [15]. It was from this trial center that resistant elm seedlings were sent to other European countries, among others, Italy in 1992 [16].

The first observation of galls on elm trees was made in $60^{\text {th }}$ in Baarn and only in $70^{\text {th }}$ they were detected in Wageningen at the trial field "Mierenbos" [6]. Presently all the Ulmus trees at that site are severely infected with Meloidogyne [27-28], as well as other two fields and local arboretum (EPPO, 2016). It is worthwhile to notice that in 2014 the outbreaks were detected for the first time on the street trees in The Hague (EPPO, 2016), although nematodes were identified as $M$. arenaria.

About the same period, root-knot nematodes found parasitizing apple trees in Japan was also misidentified as M. arenaria [15]. However, later on the species found was described and named M. mali [19-20]. It was also shown that $M$. mali could invade other plant species apart from apple tree, particularly Rosaceae [37]. Only after these discoveries M. mali was detected on elm trees in Japan. Today the list of the apple root-knot nematode host plant comprises of at least 44 species [6].

In 2006 samples of M. mali extracted from apple tree in Japan and M. ulmi obtained from elm tree in Italy were received at the Dutch National Plant Protection Organization. Nematodes from both populations were propagated and maintained on the susceptible elm variety "Wredei", after which they were investigated using morphological, biochemical and molecular methods and diagnosed as identical ones. The following investigation helped to prove the similarities and to synonymise M. mali and M. ulmi. At the same time, it was hypothesized that the apple root-knot nematode 
entered the Netherlands along with the imported infected elm root stock brought for the breeding programme from Japan [6].

Also $M$. mali has been so far detected only in the Netherlands (Baarn, Wageningen, Hague) and Italy (Pisa, Florence) there is a possibility of more wide species distribution especially in the European countries to which resistant rooted cultivars propagated on infected fields in the Netherlands had been exported. These countries include Belgium, England, France, Ireland, Spain, Denmark, Germany, Slovakia and Romania [18].

The apple root-knot nematode continues to spread out of the country of its origin Japan. In 2014 it was detected on crape myrtle plants Lagerstroemia indica L. exported from Japan to Ningbo Port (China). Five of 51 inspected trees had roots showing small and round galls $(0.4-0.7 \mathrm{~mm}$ in size) with females inside. Nematodes were also detected in the soil surrounding the roots [18].

In 2016 the apple root-knot nematode has been reported for the first time from a declining hedge of Manhattan Euonymus (Euonymus kiautschovicus Loes.) growing at a private residence in the northern part of the USA (Harrison, NY). The roots showed swelling and galls that contained rootknot nematode females. Morphological, molecular and biotest studies were conducted confirming M. mali identification. There are possibilities that occurrence and spread of $M$. mali in the USA could be the same as for the European countries as the outbreak detected was close to the two national centers leading the breeding programme targeted on resistance to the Dutch elm disease [14].

All these facts were taken into account and resulted in $M$. mali inclusion into EPPO «The Alert List» (2014) with the following pest risk analysis (PRA) at regional level. The same study was initiated in Ukraine because of suitable for $M$. mali establishment climatic conditions and presence of wide range of host plants here. The results of national PRA could be addressed to EPPO for consideration at regional level and usage for summarized analysis planned for presentation during EPPO Council meeting in autumn this year.

Materials and methods. Data of EPPO Reporting Service (2010-2016), State Statistics Committee of Ukraine, the State Veterinary and Phytosanitary Service of Ukraine, literature and the results of previous studies were used for analytical study following international standards [21-39] and recommendation [1] for pest risk analysis.

Results obtained are presented in a form of express pest risk analysis protocol.

\section{Stage I. Initiation}

1. Name and taxonomic position of the pest. Eukaryota: Metazoa: Nematoda: Meloidogynidae: Meloidogyne: Meloidogyne mali Itoh, Ohshima \& Ichinohe, 1969 (the apple root-knot nematode).

Identification of $M$. mali is based on morphological characters, which 
are the most differential for species discrimination among members of the genus Meloidogyne [10, 35]: for the second-stage juveniles - stylet knobs shape, tail shape, hyaline tail part, hemizonid position relative to secretoryexcretory pore; males - head shape, stylet knobs, lateral field, hemizonid position relative to secretory-excretory pore; female - perineal pattern, stylet knobs, secretory-excretory pore position [16, 19].

The biochemical (isozyme analysis) $[6,15-35]$ and molecular tests (SSU rDNA, LSU rDNA markers) [6, 14, 18].

2. What is the reason for performing the PRA? M. mali was detected in Europe (The Netherlands, Italy) and added to the EPPO "The Alert List" in 2014.

3. What is the PRA area? Ukraine.

\section{Stage II: Pest Risk Assessment}

1. Does the pest occur in the PRA area? No

2. What is the pest's status in the Plant Health Directive (Council Directive 2000/29/EC ${ }^{2}$ ? M. mali is not listed in the Plant Health Directive.

\begin{tabular}{|l|c|}
\hline \multicolumn{1}{|c|}{ EU Lists (Annex I, Part A, Sections) } & Yes/No \\
\hline $\begin{array}{l}\text { Section I. Harmful organisms not known to occur in any part of } \\
\text { the community and relevant for the entire community }\end{array}$ & No \\
\hline $\begin{array}{l}\text { Section II. Harmful organisms known to occur in the community } \\
\text { and relevant for the entire community }\end{array}$ & No \\
\hline
\end{tabular}

3. What is the pest's status in the European and Mediterranean Plant Protection Organization (EPPO)?

\begin{tabular}{|l|c|}
\hline \multicolumn{1}{|c|}{ EPPO Lists } & Yes/No \\
\hline A1 regulated pest list - a quarantine pest not present in the area & No \\
\hline $\begin{array}{l}\text { A2 regulated pest list - a quarantine pest present in the area but } \\
\text { not widely distributed there and being officially controlled }\end{array}$ & No \\
\hline The Alert List & $\begin{array}{c}\text { Yes } \\
\text { (since 2014) }\end{array}$ \\
\hline
\end{tabular}

4. What are the pest's host plants? The apple root-knot nematode is able to parasitize on at least 44 plant species [6].
Family
Species
Reference
Rosaceae
Malus pumila Mill.
Itoh et al. 1969
Malus prunifolia Borkh.
Itoh et al. 1969
Malus sieboldii Rehd.
Itoh et al. 1969
Malus pumila "M9"
Ahmed et al, 2013
Prunus yedoensis Matsum
Itoh et al. 1969 
Rosa hybrida Hort.

Geum coccineum Lindl.

Vitis vinifera $\mathbf{L}$.

Rubus idaeus $\mathbf{L}$.

Sorbus aucuparia $\mathbf{L}$.

Moraceae

Fagaceae

Ulmaceae

Taxaceae

Fabaceae

Solanaceae

Compositae

Umbelliferae

Leguminaceae

Urticaceae

Dryopteridaceae

Geraniaceae
Morus bombycis Koidz.

Ficus carica $\mathbf{L}$.

Maclura tricuspidata (Carriere) Bureau

Broussonetia papyrifera (L.) Vent

Broussonetia kazinoki Seibold.

Castanea crenata Seib. Et Zucc

Fagus sylvatica $\mathbf{L}$.

Quercus robur $\mathbf{L}$.

Ulmus davidiana var. japonica

Ulmus chenmoui W.C. Cheng

Ulmus glabra Hud.

Ulmus $\mathbf{Y}$ hollandica "belgica"

Acer palmatum Thunb.

Acer pseudoplatanus $\mathbf{L}$.

Trifolium repens $\mathbf{L}$.

Taxus baccata $\mathbf{L}$.

Impatiens parviflora $\mathbf{D C}$.

Solanum lycopersicum $\mathbf{L}$.

Solanum melongena $\mathbf{L}$.

Capsicum annuum $\mathbf{L}$.

Cucumis sativus $\mathbf{L}$.

Cucurbita spp.

Citrillus vulgaris Schrad. Ex Eckl. \& Zeyh.

Brassica pekinensis Rupy.

Brassica oleracea var. capitata $\mathbf{L}$.

Brassica napus var. oleifera $\mathbf{L}$.

Arcutium lappa $\mathbf{L}$.

Taraxacum officinale F.H. Wigg.

Daucus carota var. sativa $\mathbf{L}$.

Glycine $\max$ (L.) Merr.

Urtica dioica $\mathbf{L}$.

Dryopteris filix-mas (L.) Schott

Dryopteris carthusiana (Vill.) H.P. Fuchs

Geranium robertianum $\mathbf{L}$.
Itoh et al. 1969

Ahmed et al, 2013

Itoh et al. 1969

Ahmed et al, 2013

Ahmed et al, 2013

Itoh et al. 1969

Toida 1979

Toida 1979

Toida 1979

Toida 1979

Itoh et al. 1969

Ahmed et al, 2013

Ahmed et al, 2013

Toida 1979

Palmisano and Ambrogioni 2000

Palmisano and Ambrogioni 2000

Ahmed et al, 2013

Itoh et al. 1969

Ahmed et al, 2013

Itoh et al. 1969

Ahmed et al, 2013

Ahmed et al, 2013

Toida 1979

Toida 1979

Toida 1979

Toida 1979

Toida 1979

Toida 1979

Toida 1979

Toida 1979

Toida 1979

Toida 1979

Ahmed et al, 2013

Toida 1979

Toida 1979

Ahmed et al, 2013

Ahmed et al, 2013

Ahmed et al, 2013

Ahmed et al, 2013 
5. What hosts are of economic and/or environmental importance in the PRA area? The apple root-knot nematode can reproduce on various wild and cultivated plants in Ukraine used for ornamental (especially those, which are used for decorative purposes in gardens and landscape design projects) or agricultural purpose. The most imported agricultural crops potentially exposed to M. mali infection are: apple, cherry, grape, raspberry, mulberry, vegetables (tomato, eggplant, peppers, cucumber) and others.

6. If the pest needs a vector, is it present in the PRA area? No vector is required.

7. What is the pest's present geographical distribution?

Europe: The Netherlands (outbreaks in Baarn, Wageningen, The Hague; EPPO Reporting Service), Italy (outbreaks: Pisa, Florence; EPPO Reporting Service).

Asia: Japan [38], China (outbreaks) [18].

North America: USA (outbreak) [27].

8. How likely is the pest to enter the PRA area?

unlikely $\square$ low $\begin{aligned} & \text { low } \\ & \text { likelihood }\end{aligned} \quad \begin{aligned} & \text { moderate } \\ & \text { likelihood }\end{aligned} \square$ likely $\square$

M. mali can be introduced into new areas along with the infected rooted plants or soil from the infested site.

There is a high possibility of M. mali spread into Ukraine by passive pathway with infected root stock and soil as it had already been registered in the countries of the apple root-knot nematode restricted distribution

9. How likely is the pest to establish outdoors in the PRA area?

unlikely

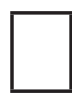
low
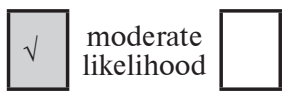

likely

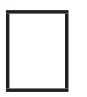

very
likely

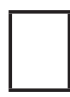

In Japan (the country of origin) M. mali complete one full generation within 18-22 weeks on the principle host (apple) once in a year. The adult males and females are observed after $12^{\text {th }}$ week and continued to increase till the $20^{\text {th }}$ week, when egg masses appear.

So far it is unknown whether M. mali could survive frost conditions of winter. Also some egg-laying female were once already found in the galls during early spring at the trial "Mierenbos" in the Netherlands, which could prove the capacity of the apple root-knot nematode to overwinter outdoors in the northern European countries. Such rare phenomenon already was registered in $M$. ardenensis [15, 39].

Additional observation proving this fact was made in the USA (Harrison, NY) where M. mali parasitizing E. kiautschovicus Loes. could withstand the minimum winter temperature $-6^{\circ} \mathrm{C}$; maximum summer temperature $+28^{\circ} \mathrm{C}$; annual precipitation $-1256.2 \mathrm{~mm}$ ). 
According to «the Kuppen-Geiger climate classification» [40] the country of $M$. mali origin Japan, the country of the apple root-knot nematode restricted distribution (The Netherlands, Italy, USA) and Ukraine have similar climatic zones.

10. How quickly could the pest spread within the PRA area?

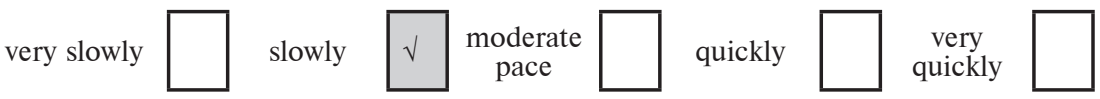

Natural migration of $M$. mali is limited, therefor spread of the nematodes over long distances is associated primarily with human activities.

11. Without official control what level of economic and/or environmental impact is the pest likely to cause in the PRA area?

minimal
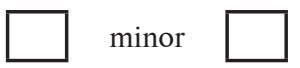
moderate

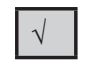

major

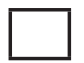

massive

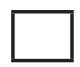

M. mali demonstrates high negative economic impact in the country of its origin [24].

12. What is the pest's potential as a vector of plant pathogens? M. mali is not known of transmitting other plant pathogens.

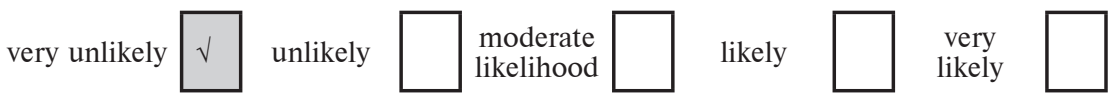

How likely are outbreaks to be eradicated?

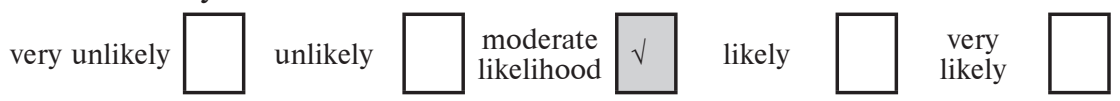

\section{Stage III. Pest risk management}

1. What management options are available for containment and control?

- before planting - No options available.

- post harvest - Crop rotation with non-host plants.

2. Phytosanitary measures to be applied on the plant product (pathway) that could prevent the introduction of the pest. Given the more than 50 -year history of the introduction and subsequent spread of M. mali in the European part of the continent, the presence of outbreaks in outdoors in the Netherlands and Italy, and the high likelihood of the spread of the apple root-knot nematode in Belgium, England, France, Ireland, Spain, Denmark, Germany, Slovakia and Romania, it is expedient to introduce inspection on rooted plants, seedlings of the pathogen host plants imported from those countries and the country of M. mali origin - Japan.

3. Further work that would reduce uncertainties. The targeted nematological survey should be carried out to clarify the likelihood of M. mali presence in Ukraine because of the more than 50-year 
history of the introduction and subsequent spread of the apple rootknot nematode in the European part of the continent. Given the existence of national breeding programme focused on resistance to the Dutch elm disease, introduction of the apple root-knot nematode could already take place with imported elm root stock as it had been reported for the Netherlands.

\section{CONCLUSIONS}

The risk of $M$. mali introduction, establishment and economic impact in Ukraine was assessed as likely, which proved the need for specific statutory actions to be taken to prevent ingress of the apple root-knot nematode and mitigate its effects in Ukraine. The necessity of the full scale pest risk analysis is proven to elaborate the optimal pest control measures to prevent the introduction, establishment and spread of the pathogen in the region.

\section{REFRERENCES}

1. Pylypenko L.A. Pest risk analysis of regulated pests in Ukraine / L.A. Pylypenko, J.D. Kudinova, V.Ya. Mar'ushkina, A.F. Ustinova, O.O. Sykalo, N.K. Filatova, N.A. Dem'yanets, L.M. Yaroshenko. - K.: Kolobih, 2012. - 56 p. (in Ukrainian)

2. Skolskiy I.M. Dutch illness of elm: distributions, stages of development, prospect and fading pre-condition / I.M. Skolskiy // Naukobyi visnyk NLTU of Ukraine. - 2009. - 19(1). - C. 33-37. (in Ukrainian)

3. Schevchenko S.V. The peculiarities of the Dutch elm disease in the western part of Ukrainian USSR / S.V. Schevchenko // Abstr. of the XXXVI scientific-technical conf.: forest section. - Lviv : LLTI, 1986. C. 17-22. 11. (in Russian)

4. Schevchenko S.V. Reduction of the Dutch elm disease harmfulness in the western part of Ukrainian USSR / S.V. Schevchenko // Организация лесохозяйственного производства охрана и защита леса : экспрессинформация. - 1987. - 3. - C. 13-15. (in Russian)

5. Adam M. A. M. Molecular diagnostic key for identification of single juveniles of seven common and economically important species of root-knot nematode (Meloidogyne spp) / M. A. M. Adam, M. S. Phillips, V. C. Blok // Plant Pathol. - 2007. - 56. - P. 190-197.

6. Ahmed M. On the species status of the root-knot nematode Meloidogyne ulmi Palmisano \& Ambrogioni, 2000 (Nematoda, Meloidogynidae) / M. Ahmed, B.T.L.H. van de Vossenberg, C. Cornelisse, G. Karssen // ZooKeys. - 2013. - 362. - P. 1-27. doi:10.3897/zookeys.362.6352

7. Anthoine G. Pest Risk Analysis for Meloidogyne enterolobii [Електронний ресурс] / G. Anthoine, J. Brito, J.M. Guitian Castrillon, Zh. Ilieva, G. Karssen, S. Kiewnick, B. Niere, R. Steffek // Назва з титул. екрану. 2010. - Режим доступу : http://www.eppo.int/ QUARANTINE/Pest_ Risk_Analysis/PRA_intro.htm. 
8. Almeidal E. J. Assinalamentos de Meloidogyne enterolobii em Goiabeira e em plantas invasoras no Estado de Sao Paulo, Brasil / E. J. Almeidal, G. C. S. Alves, J. M. Santos, A. B. G. Martins // Nematologia Brasileira. Piracicaba (SP) Brasil. - Vol. 35(1-2). - 2011. - P. 50-52.

9. Brito J. A. Morphological and molecular characterization of Meloidogyne mayaguensis from Florida / J. A. Brito, T. O. Powers, P. G. Mullin, R. N. Inserra, D. W. Dickson // Journal of Nematology. - 2004. - 36. P. 232-240.

10. Braasch $H$. Establishment potential and damage probability of Meloidogyne chitwoodi in Germany / H. Braasch, U. Wittchen, J.G. Unger // Bulletin OEPP/EPPO Bulletin. - 1996. - 26. - P. 495-509.

11. Blok V. C. Mitochondrial DNA differences distinguishing Meloidogyne mayaguensis from the major species of tropical root-knot nematodes // V. C. Blok, J. Wishart, M. Fargette, K. Berthier, M. S. Philips // Nematology. - 2002. - 4. - P. 773-781.

12. Blok V.C. Biochemical and molecular identification / V.C. Blok, T.O. Powers // In: Root-knot Nematodes. - R. Perry, M. Moens, J. Starr (eds). - CABI Publishing, Wallingford, UK, 2009. - P. 98-118.

13. Carneiro R. M. D. G. First record of Meloidogyne mayaguensis on guave in Brazil / R. M. D. G. Carneiro, W. A. Moreira, M. R. A. Almeida, A. C. M. M. Gomes // Nematologia Brasileira. - 2001. - 25(2). P. 223-228.

14. Eisenback J.D. First report of the apple root-knot nematode (Meloidogyne mali) in North America, found parasitizing Euonymus in New York / J.D. Eisenback, L. Graney, P. Vieira // Plant Disease. - 2016. http://dx.doi.org/10.1094/PDIS-06-16-0894-PDN.

15. Esbenshade P. Use of enzyme phenotypes for identification of Meloidogyne species / Esbenshade P., Triantaphyllou A. // Journal of Nematology. - 1985. - 17. - P. 6-20.

16. Heybroek H.M. The Dutch elm breeding program. In: Dutch elm disease research: Cellular and molecular approaches / Sticklen M.B., Sherald J.L. (eds). Springer-Verlag, NY, 1993. - P. 16-25. doi: 10.1007/978$1-4615-6872-8 \quad 3$

17. Hunt D.J. Taxonomy, identification and principal species / D.J. Hunt, Z.A. Handoo // Root Knot Nematodes / R.N. Perry, M. Moens, J. Star (eds.). - CABI, 2009. - P. 55-97.

18. Gu J.F. First report of the apple root-knot nematode, Meloidogyne mali, infecting crape Myrtle from Japan / J.F. Gu, J. He // Plant Disease. - 2015. - 99(6). - P. 893. - http://dx.doi.org/10.1094/PDIS-1114-1145-PDN.

19. Itoh $Y$. A rootknot nematode Meloidogyne mali $\mathrm{n}$ sp on apple tree from Japan (Tylenchida, Heteroderidae) / Y. Itoh, Y. Ohshima, M. Ichinohe // Applied Entomology and Zoology. - 1969. - 4. - P. 194-202. 
20. Inagaki $H$. Apple root-knot nematode, Meloidogyne mali, its taxonomy, ecology, damage, and control / H. Inagaki // Kasetsart Journal. 1978. - 12(1). - P. 25-30.

21. ISPM 1: Phytosanitary principles for the protection of plants and the application of phytosanitary measures in international trade, 2006. Rome, IPPC, FAO.

22. ISPM 2: Guidelines for pest risk analysis, 1996. FAO, Rome.

23. ISPM 11: Pest risk analysis for quarantine pests, including analysis of environmental risks and living modified organisms, 2004. FAO, Rome.

24. ISPM 21: Pest risk analysis for regulated non-quarantine pests, 2004. FAO, Rome.

25. Jepson S.B. Identification of root-knot nematodes (Meloidogyne species). - Commonwealth Agricultural Bureaux, Farnham Royal, UK, 1987. - $265 \mathrm{p}$.

26. Karssen G. Meloidogyne ulmi: een nieuwe iepen parasiet in Nederland? / G. Karssen, I. van Keulen, T. van Hoenselaar, E. van Heese // Boomzorg. - 2008. - 1. - P. 62-63.

27. Karssen $G$. Een Nieuwe iepenwortelparasiet. In: Iep of Olm: Karakterboom van de Lage Landen / Heybroek H.M., Goudzwaard L., Kaljee H. (eds). KNNV Uitgeverij, Zeist, 2009. - P. 132.

28. Karssen G., Moens M. Root-knot nematodes. In: Plant Nematology / R.N. Perry, M. Moens (eds). - CAB International, Wallingford, UK, 2006. - P. 59-90.

29. Karssen $G$. The plant-parasitic nematode genus Meloidogyne Göldi, 1892 (Tylenchida) in Europe. Brill Academic Publishers, Leiden, The Netherlands, 2002. - $161 \mathrm{p}$.

30. Kottek M. World Map of the Köppen-Geiger climate classification updated / M. Kottek, J. Grieser, C. Beck, B. Rudolf, F. Rubel // Meteorol. Z. -2006 . - 15. - P. 259-263.

31. PM 5/2 (2) Guidelines on pest risk analysis (PRA). No. 2. Pest risk analysis, 2009, EPPO, Paris.

32. PM 5/3 (5) Guidelines on pest risk analysis (PRA). No. 3. Pest risk assessment scheme, 2011. EPPO, Paris.

33. Palmissano A. Meloidogyne ulmi sp. n., a root-knot nematode from elm / A. Palmissano, L. Ambrogioni // Nematologia Mediterranea. - 2000. 28. - P. 279-293. http://journals.fcla.edu/nemamedi/article/ view/63531

35. Santo G. S. Biology and management of root-knot nematodes on potato in the Pacific Northwest. In: Advances in potato pest biology and management. - G. W. Zehner, M. L. Powelson, R. K. Jansson, K. V. Raman (eds.). - APS Press St. Paul, USA, 1994. - P. 193 - 201.

36. Sakai $H$. Root-knot nematodes parasitizing the Japanese flowering cherry trees. / H. Sakai, T. Mizukubo // Abstract of papers presented at the 17th meeting of the Japanese Nematological Society, Kumamoto, Japan, 
September 3-5, 2009. - Japanese Journal of Nematology. — 2009. 39. - P. 74.

37. Stephan Z.A. Population fluctuation, life cycle of root-knot nematode, Meloidogyne ardenensis in Cupar, Scotland, and the effect of temperature on its development / Z.A. Stephan, D.L. Trudgill // Revue de Nematologie. - 1982. - 5. - P. 281-284.

37. Nyczepir A. P. Nematode pests of deciduous fruit and nut trees / A.P. Nyczepir, J.M. Halbrendt. In: Plant parasitic nematodes in temperate agriculture // K. Evans, D.L. Trudgill, J.M. Webster (eds.). - Wallingford, UK: CAB International, 1993. - P. 381-425.

38. Toida $Y$. Host plants and morphology of the 2nd-stage larvae of Meloidogyne mali from mulberry / Y. Toida // Japanese Journal of Nematology. - 1979. - 9. - P. 20-24.

39. Tiilikkala K. Pest risk analysis of Meloidogyne chitwoodi for Finland / K. Tiilikkala, T. Carter, M. Heikinheimo, A. Venalainen // Bulletin OEPP/ EPPO Bulletin. - 1995. - 25. - P. 419-435.

40. Rammah A. Meloidogyne mayaguensis n. sp. (Meloidogynidae), a root-knot nematode from Puerto Rico / A. Rammah, H. Hirschmann // Journal of Nematology. - 1988. - 20. - P. 58-69.

\section{Пилипенко Л.А. Експрес-аналіз фітосанітарного ризику від Meloidogyne mali}

Проведено експрес-аналіз фітосанітарного ризику від Meloidogyne mali для України, що зумовлено виявленням первинного вогнища иього виду y 2012-2013 рр. у Нідерландах $і$ згодом - в Італії, та включенням виду до Попереджувального списку Європейської та Середземноморської організації карантину $i$ захисту рослин у 2014 р. Ризик проникнення, акліматизації та негативного економічного впливу від M. mali на території України оцінено як ймовірний, чим доведено необхідність здійснення повного аналізу фітосанітарного ризику задля пошуку заходів фітосанітарного контролю з метою попередження інтродукції, акліматизації та ймовірного поширення виду в регіоні.

\section{Пилипенко Л.А. Экспресс-анализ фитосанитарного риска от Meloidogyne mali}

Проведен экспресс-анализ фитосанитарного риска от Meloidogyne mali для Украины, что было обусловлено недавним (2012-2013 гг.) выявлением первичного очага яблоневой галловой нематоды в Нидерландах, позднее - в Италии и включением вида в предупредительный список EOКЗР (The Alert List) в 2014 году. Риск проникновения, акклиматизации и негативного экономического воздействия от M. mali на территории Украины оценивается как вероятный, чем доказано целесообразность его фитосанитарного регулирования. Полученные выводы доказывают необходимость проведения полного анализа фитосанитарного риска. 